\title{
Neuroticism, Trait Fear of Missing Out, and Phubbing: The Mediating Role of State Fear of Missing Out and Problematic Instagram Use
}

\author{
Sabah Balta ${ }^{1}$ Emrah Emirtekin ${ }^{2}$. \\ Kagan Kircaburun $^{3}$ - Mark D. Griffiths ${ }^{4}$ (D)
}

Published online: 12 July 2018

(C) The Author(s) 2018

\begin{abstract}
One of the relatively new negative consequences of smartphone use is "phubbing" (snubbing someone while an individual checks their smartphone in the middle of a real-life conversation). The purpose of the present study was to investigate the direct and indirect associations of neuroticism, trait anxiety, and trait fear of missing out with phubbing via state fear of missing out and problematic Instagram use. A total of 423 adolescents and emerging adults aged between 14 and 21 years (53\% female) participated in the study. Findings indicated that females had significantly higher scores of phubbing, fear of missing out, problematic Instagram use, trait anxiety, and neuroticism. Path analysis showed that trait fear of missing out and neuroticism were indirectly associated with phubbing via state fear of missing out and problematic Instagram use. State fear of missing out was directly and indirectly associated with phubbing via problematic Instagram use. The present study is the first to demonstrate empirical evidence for the relationship between different dimensions of fear of missing out, problematic Instagram use, and phubbing.
\end{abstract}

Mark D. Griffiths

mark.griffiths@ntu.ac.uk

Sabah Balta

sabah.balta@yasar.edu.tr

Emrah Emirtekin

emrah.emirtekin@yasar.edu.tr

Kagan Kircaburun

kircaburunkagan@gmail.com

1 Faculty of Economics and Administrative Sciences, Yaşar University, İzmir, Turkey

2 The Centre for Open and Distance Learning, Yaşar University, İzmir, Turkey

3 Faculty of Education, Duzce University, Duzce, Turkey

4 International Gaming Research Unit, Psychology Department, Nottingham Trent University, Nottingham, UK 
Keywords Neuroticism $\cdot$ Anxiety $\cdot$ Fear of missing out $\cdot$ Problematic Instagram use $\cdot$ Phubbing

With the increasing use of Internet applications such as social media, gaming, and gambling (Pontes et al. 2015) and the developments in mobile technologies, smartphones have become essential in individuals' everyday lives. Nowadays, smartphones are used for various reasons and uses other than simply making a call. Their introduction has led to widespread usage of smartphones worldwide. In 2018, 36\% of all the people living in the world were smartphone users (Statista 2018a). In 2017, more than 50\% of all the people living in Turkey (where the present study was carried out) were smartphone users and these numbers are expected to rise in the upcoming years (Statista 2018b).

With so many individuals using smartphones, research has demonstrated that a small minority of its users appear to experience problematic smartphone use (Billieux et al. 2015). Phubbing, which is a newly emerging phenomenon concerning smartphone use, has recently drawn attention from academics. The term "phubbing" is derived from the words "phone" and "snubbing," and refers to individuals checking their smartphone in the middle of a real-life conversation with someone else and escaping from interpersonal communication (Karadağ et al. 2015). Phubbing can be considered a disrespectful behavior towards others and can damage real-life social relationships with others (Karadağ et al. 2015). It can have a direct negative impact on relationship satisfaction, and an indirect impact on life satisfaction and depression via relationship satisfaction (Roberts and David 2016), which may be explained by the heightened feelings of jealousy (Krasnova et al. 2016). Consequently, phubbing can be a problematic behavior that may harm both phubbers and those being phubbed (Chotpitayasunondh and Douglas 2016). Consequently, the personality and psychological risk factors that may lead to phubbing should be further examined.

Even though it is a relatively new phenomenon, different studies have investigated related factors and consequences of phubbing. To date, addictive use of technological mediums such as mobile phones, Internet, social media, games, and Facebook have been shown to increase phubbing (Błachnio and Przepiorka 2018; Karadağ et al. 2015). Gender has been shown to be a moderating variable with females engaging in phubbing more than males (Karadağ et al. 2015) and that phubbing may become a norm because of observed and personal behaviors. For instance, the social norms of phubbing have been associated with phubbing and being phubbed, while phubbing has been related to being phubbed (Chotpitayasunondh and Douglas 2016).

Despite the growing body of literature, little is known about the complex relationships of emotional and impulsive personality constructs such as trait anxiety and neuroticism in relation to phubbing. Moreover, even though phubbing has been assumed and speculated to emerge from fear of missing out (FoMO) in previous studies, no empirical study has ever demonstrated the relationship between phubbing and FoMO. Finally, despite the growing body of evidence concerning the impact of problematic smartphone use (including problematic social media use) on phubbing, the role of specific problematic social media use (i.e., Instagram) has yet to be empirically investigated. Given the theoretical models suggesting different risk factors and consequences for different types of specific Internet-use disorders (Brand et al. 2016), it is theoretically reasonable to expect problematic Instagram use (PIU) to have a unique effect on phubbing. Therefore, the present study investigates the direct and indirect associations of neuroticism, trait anxiety, and trait fear of missing out with phubbing via state fear of missing out and problematic Instagram use. 


\section{Neuroticism, Trait Anxiety, and Phubbing}

Neuroticism is defined as "a tendency to experience negative emotional states, accompanied by heightened anxiety or depression, anger and guilt, as well as increased tendency for somatization of psychological problems" (Gonda et al. 2009; p. 107). Neurotic individuals have an overall anxious predisposition and tendency to worry (Mehroof and Griffiths 2010). Even though there is no empirical evidence (except the ones indicating an association between neuroticism and problematic smartphone use (Billieux et al. 2007)), given the emotionally unstable and impulsive nature, and lower self-control of individuals with higher neuroticism (Fetterman et al. 2010), it is theoretically reasonable to assume that neuroticism is associated with higher levels of phubbing.

Trait anxiety is defined as "the general tendency of an individual to be upset in stressful situations, or as the mean level of anxiety over a longer period" (Demyttenaere et al. 1989; p. 943). Trait anxiety and neuroticism, which are highly overlapping constructs, are being considered similar personality constructs (Jorm 1989), and anxious individuals have consistently been shown to experience increased level of problematic smartphone use (Demirci et al. 2015). Therefore, it is expected that there will be a similar heightening effect on phubbing behavior arising from trait anxiety. The purpose of testing these similar constructs together is to be able to understand which of the two may better explain phubbing.

\section{Fear of Missing Out and Phubbing}

Fear of missing out is defined as "a pervasive apprehension that others might be having regarding experiences from which one is absent” (Przybylski et al. 2013; p. 1842). It is logical to assume that individuals experiencing higher levels of FoMO will harbor higher facets of personality constructs such as trait anxiety, neuroticism, irritability, inadequacy, and low selfesteem (Abel et al. 2016; Oberst et al. 2017). Despite the fact that FoMO is an emerging construct in a technological context, there has been a growing empirical literature investigating the role of this phenomenon on problematic online behaviors (Kuss and Griffiths 2017). Some of these studies have found that FoMO is associated with higher problematic smartphone and social media use (Chotpitayasunondh and Douglas 2016; Elhai et al. 2016; Oberst et al. 2017; Wegmann et al. 2017), which are also predictors of phubbing (Karadağ et al. 2015).

A recent study assumed that FoMO may be a more complex construct that could refer to a specific cognition such as an online fear of missing out rather than a unitary phenomenon (Wegmann et al. 2017). Therefore, they approached FoMO as a multi-dimensional construct that comprised dispositional trait-FoMO, which refers to a stable individual characteristic, and state-FoMO, which refers to a FoMO of online content and interactions with others (Wegmann et al. 2017). Moving from a recent theoretical model, state-FoMO was included into specific cognition category which may play a mediating role between trait-FoMO and problematic use of Internet applications (Brand et al. 2016). Consequently, the present study expected to find a mediating role of state-FoMO between the relationships of trait-FoMO, neuroticism, and trait anxiety with phubbing.

\section{The Mediating Role of Problematic Instagram Use}

Despite the growing body of Internet-use disorder literature (Kircaburun et al. 2018), very little is known about the risk factors and consequences of problematic Instagram use. Recent studies with university students found that problematic Instagram use is associated with lower selfliking, agreeableness and conscientiousness, watching live streams of others, leaving "likes" and 
comments on others' posts, perceived feeling of presence, and escapism (Kircaburun and Griffiths 2018a, 2018b). It was argued in these studies that the relationship of watching live streams of others and leaving "likes" and comments on others' posts with problematic Instagram use may be explained by the fear of missing out on recent developments of and interactions with peers. Moreover, the theoretical assumptions for individuals with higher emotional instability, impulsivity, irritableness, and anxiety to have increased levels of Internet-use disorders have been supported by empirical studies (Brand et al. 2016; Kuss and Griffiths 2011, 2012). Therefore, it is reasonable to expect that neuroticism, trait anxiety, trait-FoMO, and stateFoMO will be associated with higher engagement in problematic Instagram use.

Additionally, and as previously mentioned, phubbing has been associated with addictions to social media, mobile phones, gaming, and the Internet (Karadağ et al. 2015), although specific role of problematic Instagram use is unknown. Obviously, it is logical to expect an augmenting effect from problematic Instagram use on phubbing, but it is still important to identify the specific contribution of problematic Instagram use and compare it with the role of other specific Internet-use disorders on phubbing because different applications and platforms may have different features and varied outcomes (Brand et al. 2016).

\section{The Present Study}

Based on the aforementioned studies and theoretical assumptions, the present study tested a complex model in which neuroticism, trait anxiety, and trait-FoMO were independent variables, state-FoMO and problematic Instagram use were mediator variables, and phubbing was the outcome variable. It was hypothesized that neuroticism, trait anxiety, and trait-FoMO would be positively directly and indirectly associated with phubbing via state-FoMO and problematic Instagram use, whereas state-FoMO would be positively directly and indirectly associated with phubbing via problematic Instagram use.

\section{Methods}

\section{Participants}

Participants were recruited using a mixed methods approach. The study was first promoted via social media groups and 121 individuals completed an online survey. Given the lower than expected number of participants, the same survey was administered (offline and in class) to students attending a high school and a state university in northern region of Turkey using paper-pencil questionnaires. The final sample comprised 423 Instagram users, aged between 14 and 21 years $\left(M_{\text {age }}=17.15\right.$ years, $\mathrm{SD}=2.24 ; 53 \%$ female $)$. The only inclusion criterion for participation in the study was to have an active Instagram account. All of the participants gave their informed consent and took part the study voluntarily and anonymously.

\section{Measures}

\section{Social Media Use Questionnaire}

The Social Media Use Questionnaire (SMUQ) (Xanidis and Brignell 2016) assesses problematic use of social media and comprises nine items (e.g., "I feel anxious, when I am not able to 
check my social network account") on a 5-point Likert scale from "never" to "always," with two factors (i.e., withdrawal and compulsion). In the present study, in order to assess problematic Instagram use, the SMUQ was used by replacing "social media" with "Instagram." Previous studies with the Turkish form reported optimal validity and reliability for the scale (Kircaburun and Griffiths 2018a, b). Cronbach's alphas for this and the other scales used in the present study are shown in Table 2.

\section{Fear of Missing Out Scale}

The Fear of Missing Out Scale (FoMOS) (Wegmann et al. 2017) assesses different levels of fear of missing out, and comprises 12 items on a 5-point Likert scale from "never" to "always," with two factors: trait-FoMO (e.g., "I fear my friends have more rewarding experiences than me") and state-FoMO (e.g., "I am continuously online in order not to miss out on anything"). The Turkish form of the scale was used for the first time in the present study. Therefore, confirmatory factor analysis (CFA) was applied for adaptation. According to CFA results ( $\chi^{2} / \mathrm{df}=3.80$, $\mathrm{RMSEA}=.08(\mathrm{CI} 90 \%[.07, .09]), \mathrm{SRMR}=.02, \mathrm{CFI}=.93, \mathrm{GFI}=.93)$, the scale was valid and reliable for assessing trait-FoMO and state-FoMO levels among Turkish participants. The internal consistency coefficients of the subscales were also high $(.78, .85)$.

\section{The Phubbing Scale}

The Phubbing Scale (TPS) (Karadağ et al. 2015) comprises 10 items on a 5-point Likert scale from "never" to "always," with two factors (five items for each factor): communication disturbances (e.g., "My eyes start wandering on my phone when I'm together with others") and phone obsession (e.g., "When I wake up in the morning, I first check the messages on my phone"). Previous studies have reported optimal validity and reliability of the scale (Karadağ et al. 2015). Internal consistency values of the subscales were also high in the present study $(.77, .79)$.

\section{Neuroticism Subscale}

The neurotic personality traits of the participants were assessed by using the neuroticism subscale of the Adjective Based Personality Scale (ABPT). ABPT-neuroticism comprises seven items on a 7-point Likert scale (Bacanlı, İlhan, \& Aslan, 2009). Because the internal consistency value of the scale turned out to be low (.49), confirmatory factor analysis was applied. As a result of CFA, it was observed that Items 2, 3, 5, and 7 had unacceptable standardized regression weights $(<.30)$ and squared multiple correlations $(<.10)$. Consequently, these items were removed from the analyses. The final three-item structure ("I see myself as an impatient person," "I see myself as a pessimistic person," and "I see myself as a restless person") indicated adequate validity and reliability of the reduced scale (.64).

\section{State-Trait Anxiety Inventory Short Form}

The State-Trait Anxiety Inventory Short Form (STAI-6) (Marteau and Bekker 1992) comprises six items (e.g., "I feel calm," "I am worried") on a 4-point Likert scale from "almost never" to "almost always." Previous studies have reported optimal validity and reliability of the scale (Öner and Le Compte 1985). The present study used the Turkish translation of the original 20item version of the STAI (Le Compte and Oner 1976). 


\section{Statistical Analysis}

In order to analyze the data frequency and descriptive statistics, Pearson correlation tests, $t$-tests, confirmatory factor analyses, and path analyses were applied using SPSS 23.0 and AMOS 23.0 software. In order to use path analysis or structural equation modeling, the sample size should be higher than 200 (Haenlein and Kaplan 2004; Nasser and Wisenbaker 2003). Total (direct and indirect) effects of independent and mediator variables on the outcome variable were calculated via using bootstrapping method with 5000 bootstrap samples and 95\% bias-corrected confidence intervals. Finally, total, female and male samples were analyzed separately. In the CFA and path analyses, goodness of fit criteria determined by $\mathrm{Hu}$ and Bentler (1999) were used in order to designate model fit.

\section{Results}

Results of the $t$ tests regarding the score differences across females and males are presented in Table 1. All study variables, except state-FoMO, differed significantly between female and male adolescents and emerging adults. Females had higher levels of phubbing, problematic Instagram use (PIU), trait-FoMO, neuroticism, and trait anxiety scores compared to males. Results of the mean scores, standard deviations, score ranges, Cronbach's alphas, and Pearson correlation coefficients are presented in Table 2. Problematic Instagram use, state-FoMO, and trait-FoMO were highly correlated with phubbing. Neuroticism and trait anxiety were weakly correlated with phubbing (Table 3).

In order to test the hypothesized model (Fig. 1), path analysis was applied (Fig. 2). As a result, model indicated good fit to the data $\left(\chi^{2} / \mathrm{df}=2.96, \mathrm{RMSEA}=.07\right.$ (CI 90\% $\left.[.04, .10]\right)$, $\mathrm{SRMR}=.02, \mathrm{CFI}=.99, \mathrm{GFI}=.98)$. State-FoMO $(\beta=.30, p<.001 ; 95 \% \mathrm{CI}[.16, .43])$ and PIU $(\beta=.54, p<.001 ; 95 \%$ CI $[.37, .71])$ were moderately directly associated with phubbing while trait-FoMO $(\beta=.35, p<.001 ; 95 \%$ CI $[.26, .44])$ and neuroticism $(\beta=.09, p<.05 ; 95 \%$ CI $[.00, .19])$ were indirectly associated with phubbing via state-FoMO and PIU respectively. The multiple mediation model explained $25 \%$ of state-FoMO, $50 \%$ of PIU, and $73 \%$ of the phubbing (Table 4).

\section{Discussion}

The present study investigated the direct and indirect associations between neuroticism, trait anxiety, and trait fear of missing out with phubbing via state-FoMO and

Table 1 Comparison of the scores of study variables ( $t$ test) between females and males

\begin{tabular}{lllll}
\hline & Female $(N=226)$ & Male $(N=197)$ & $t$ test & Cohen's d \\
\hline Phubbing & $24.09 \pm 8.34$ & $20.38 \pm 7.56$ & $4.77 * * *$ & .05 \\
Problematic Instagram use & $27.50 \pm 8.58$ & $25.82 \pm 8.25$ & $2.05^{*}$ & .02 \\
State-FoMO & $17.59 \pm 6.56$ & $16.55 \pm 6.12$ & 1.67 & .02 \\
Trait-FoMO & $13.56 \pm 4.66$ & $12.64 \pm 4.65$ & $2.07 *$ & .02 \\
Neuroticism & $11.31 \pm 4.23$ & $10.06 \pm 4.36$ & $2.99 * *$ & .03 \\
Trait anxiety & $13.77 \pm 3.42$ & $12.69 \pm 3.37$ & $3.26^{* *}$ & .03 \\
\hline
\end{tabular}

FoMO, fear of missing out; $* p<.05 ; * * p<.01 ; * * * p<.001$; mean $\pm \mathrm{SD}$ 
Table 2 Mean scores, standard deviations, score ranges, Cronbach's alphas, and Pearson correlation coefficients of the study variables

\begin{tabular}{|c|c|c|c|c|c|c|}
\hline & 1. & 2. & 3. & 4. & 5. & 6. \\
\hline 1. Phubbing & - & & & & & \\
\hline 2. Problematic Instagram use & $.65 * * *$ & - & & & & \\
\hline 3. State-FoMO & $.65 * * *$ & $.60 * * *$ & - & & & \\
\hline 4. Trait-FoMO & $.44 * * *$ & $.38 * * *$ & $.50 * * *$ & - & & \\
\hline 5. Neuroticism & $.28 * * *$ & $.26 * * *$ & $.15^{* *}$ & $.29 * * *$ & - & \\
\hline 6. Trait anxiety & $.18 * * *$ & $.18 * * *$ & .09 & $.21 * * *$ & $.53 * * *$ & - \\
\hline Mean & 26.71 & 22.36 & 17.11 & 13.13 & 10.73 & 13.27 \\
\hline $\mathrm{SD}$ & 8.46 & 8.19 & 6.37 & 4.59 & 4.33 & 3.43 \\
\hline Score ranges & $10-50$ & $9-45$ & $7-35$ & $5-25$ & $3-21$ & $6-24$ \\
\hline Cronbach's Alpha & .86 & .89 & .85 & .78 & .63 & .77 \\
\hline
\end{tabular}

FoMO, fear of missing out; $* p<.05 ; * * p<.01 ; * * * p<.001$

problematic Instagram use. According to the path analysis, (i) neuroticism was indirectly associated with phubbing via problematic Instagram use, (ii) trait-FoMO was indirectly associated with phubbing via state-FoMO and state-FoMO $\rightarrow$ problematic Instagram use pathways, and (iii) state-FoMO was directly and indirectly associated with phubbing via problematic Instagram use. The results confirm the I-PACE model which asserts that an individuals' core characteristics are associated with Internet-use disorders, and specific cognitions can mediate this relationship (Brand et al. 2016).

Partially parallel to the hypothesis, the neuroticism was indirectly associated with phubbing via problematic Instagram use. Neuroticism was related to higher problematic Instagram use, and in turn, problematic Instagram use led to higher phubbing. This finding contradicts with the result of a recent study (Kircaburun and Griffiths 2018a). However, the aforementioned study included other personality traits in the

Table 3 Standardized estimates of total, direct, and indirect effects on problematic social media use and mediator variables

Total sample effect (S.E.)

T-FoMO $\rightarrow$ Phubbing (total effect)
T-FoMO $\rightarrow$ Phubbing (direct effect)
T-FoMO $\rightarrow$ Phubbing (total indirect effect)
T-FoMO $\rightarrow$ S-FoMO $\rightarrow$ Phubbing
T-FoMO $\rightarrow$ S-FoMO $\rightarrow$ PIU $\rightarrow$ Phubbing
NEU $\rightarrow$ Phubbing (total effect)
NEU $\rightarrow$ Phubbing (direct effect)
NEU $\rightarrow$ Phubbing (total indirect effect)
NEU $\rightarrow$ PIU $\rightarrow$ Phubbing
S-FoMO $\rightarrow$ Phubbing (total effect)
S-FoMO $\rightarrow$ Phubbing (direct effect)
S-FoMO $\rightarrow$ PIU $\rightarrow$ Phubbing (total indirect effect)

$.43 * * *(.05)$
$.08(.05)$
$.35 * * *(.05)$
$.15 * * *(.03)$
$.17 * * *(.03)$
$.19 * *(.06)$
$.10(.05)$
$.09 *(.05)$
$.08 * *(.03)$
$.64 * * *(.04)$
$.30 * * *(.07)$
$.34 * * *(.06)$

$T-F O M O$, trait fear of missing out; S-FoMO, state fear of missing out; PIU, problematic Instagram use; $N E U$, neuroticism; S.E., standard error; $* p<.05 ; * * p<.01 ; * * * p<.001$

Only significant indirect effects are shown in the table 


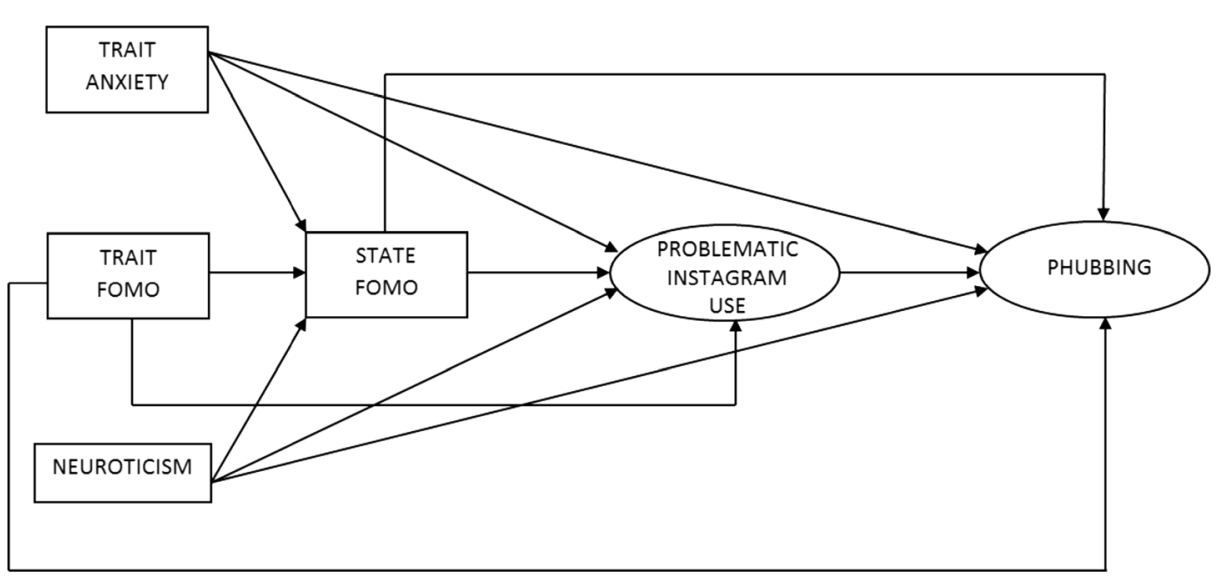

Fig. 1 Hypothesized model. For clarity, correlations between the independent variables have not been depicted in the figure

model, and reported the significant effects of agreeableness and conscientiousness, whereas the present study considered trait anxiety and trait-FoMO rather than Big Five traits. The unstable and impatient nature of neurotics may lead them to get angry quickly and perceive life negatively (McCrae and John 1992). This may put them at a heightened risk for experiencing problematic real-life social relationships and avoiding real-life interactions via engaging in excessive online use. Indeed, Instagram is a good fit for individuals to spend excessive time via looking at the constant flow of photos and videos from various interesting lifestyles of individuals (e.g., celebrities) (Kircaburun and Griffiths 2018a).

Partially parallel to the predicted hypothesis, trait-FoMO was indirectly associated with problematic Instagram use and phubbing via state-FoMO. Trait-FoMO was related to state-FoMO and in turn, state-FoMO was related to problematic Instagram

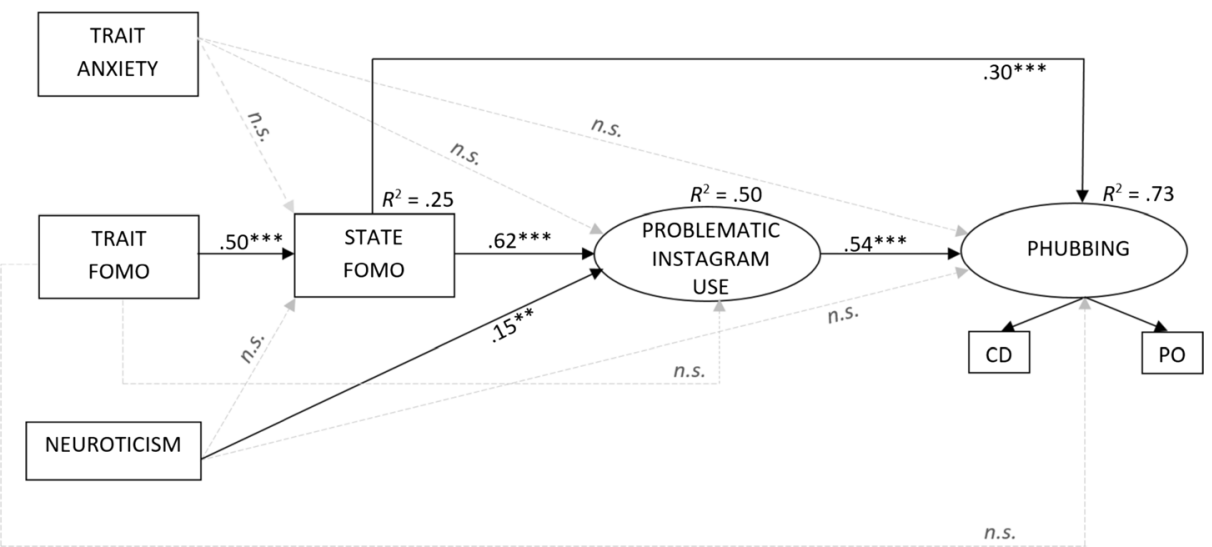

Fig. 2 Final three models of the significant path coefficients between variables. For clarity, sub-factors of Problematic Instagram Use Scale (i.e., withdrawal and compulsion), correlations between the predictor variables and insignificant path coefficients have not been depicted in the figure. Note: FOMO, fear of missing out; $\mathrm{C}$, compulsion; CD, communication disturbances; PO, phone obsession; $* p<.05 ; * * p<.01 ; * * *<<.001$ 
use and phubbing. With its facilitation of online posts (photos, videos, comments, etc.), Instagram is highly appealing for individuals who have higher levels of trait and state-FoMO, and recreational use may easily turn into excessive and compulsive use because - at present-Instagram is a popularly used application for letting others know what is new and what is going on in their lives with live streams and stories (Kircaburun and Griffiths 2018b).

As hypothesized, problematic Instagram use was directly associated with phubbing. This finding is parallel to the previous studies that have found positive relationships between different Internet-use disorders and phubbing (Błachnio and Przepiorka 2018; Karadağ et al. 2015). Even though these results belong to the present sample, it may still be worthwhile to compare different models' prediction proportions in phubbing variance. For example, a recent model explained 54\% of it using addictions to the Internet, social media, mobile phones, and gaming as predictors (Karadağ et al. 2015), while the present study explained $73 \%$ of phubbing with FoMO and problematic Instagram use. It could be speculated that problematic use of Instagram in particular may be a better predictor of phubbing because every platform has a unique characteristic and popularity. Thus, future studies could focus on the predictor role of different social media applications at the same time. Finally, the present study found that female students had higher levels of phubbing and problematic Instagram use when compared to males. This result is consistent with previous studies (e.g., Błachnio and Przepiorka 2018; Karadağ et al. 2015).

The present study has several limitations. The sample was cross-sectional and nonrepresentative; therefore, the results are unable to demonstrate any causal relationships between the variables examined. Consequently, future studies should use longitudinal designs in order to confirm causal relationships between variables examined in the present study. Data regarding neuroticism, trait Anxiety, FoMO, problematic Instagram use, and phubbing were collected using self-report methods; therefore, several biases may be affecting the results such as social desirability and memory recall. Future studies should use other methodologies (e.g., qualitative or mixed methods) in order to collect data that overcomes some of the problems inherent in using survey methods only.

Despite its limitations, the present study is the first to empirically demonstrate that neuroticism, trait and state fear of missing out, and problematic Instagram use are directly and/or indirectly associated with phubbing. However, future studies are needed to confirm the findings reported here and should also focus on more detailed and complex investigations of the relationships between the constructs here and other personality and psychological domains.

Compliance with Ethical Standards This study complies with all ethical standards.

Conflict of Interest The authors declare that they have no conflict of interest.

Ethical Approval All procedures performed in this study involving human participants were in accordance with the ethical standards of University's Research Ethics Board and with the 1975 Helsinki Declaration.

Informed Consent Informed consent was obtained from all participants. 


\section{Appendix}

Table 4 Fear of Missing Out Scale (Turkish version)

\begin{tabular}{|c|c|c|c|c|c|}
\hline & $\begin{array}{l}1 \text { = Hiçbir } \\
\text { Zaman }\end{array}$ & $2=$ Nadiren & $3=$ Bazen & $\begin{array}{l}4=\text { Çoğu } \\
\text { zaman }\end{array}$ & $\begin{array}{l}5=\text { Her } \\
\text { Zaman }\end{array}$ \\
\hline $\begin{array}{l}\text { 1. Başkalarının benimkilerden daha doyurucu } \\
\text { deneyimler yasadığından korkarım. }\end{array}$ & 1 & 2 & 3 & 4 & 5 \\
\hline $\begin{array}{l}\text { 2. Arkadaşlarımın benimkilerden daha doyurucu } \\
\text { deneyimler yașadığından korkarım. }\end{array}$ & 1 & 2 & 3 & 4 & 5 \\
\hline $\begin{array}{l}\text { 3. Arkadaşlarımın ben yokken eğlendiklerini } \\
\text { öğrendiğimde üzülürüm. }\end{array}$ & 1 & 2 & 3 & 4 & 5 \\
\hline $\begin{array}{l}\text { 4. Arkadaşlarımın neler yaptığını bilmediğimde } \\
\text { huzursuz hissederim. }\end{array}$ & 1 & 2 & 3 & 4 & 5 \\
\hline $\begin{array}{l}\text { 5. Planlanmıș bir buluşmayı kaçırmıș olmak } \\
\text { canımı sıkar. }\end{array}$ & 1 & 2 & 3 & 4 & 5 \\
\hline $\begin{array}{l}\text { 6. Hiçbir șey kaçırmamak için sürekli çevrimiçi } \\
\text { olurum. }\end{array}$ & 1 & 2 & 3 & 4 & 5 \\
\hline $\begin{array}{l}\text { 7. Sosyal ağlarda olan son durumlarla ilgili } \\
\text { yorum yapmak benim için önemlidir } \\
\text { (videolar, resimler, paylașımlar vb.). }\end{array}$ & 1 & 2 & 3 & 4 & 5 \\
\hline $\begin{array}{l}\text { 8. Sosyal ağ profillerimin güncel olmamasından } \\
\text { korkarım. }\end{array}$ & 1 & 2 & 3 & 4 & 5 \\
\hline $\begin{array}{l}\text { 9. Hiçbir șey kaçırmamak için sürekli cep } \\
\text { telefonuma bakarım. }\end{array}$ & 1 & 2 & 3 & 4 & 5 \\
\hline $\begin{array}{l}\text { 10. Güzel vakit geçirdiğimde ayrıntıları sosyal } \\
\text { medyada paylaşmak benim için önemlidir } \\
\text { (durum güncelleme vb.). }\end{array}$ & 1 & 2 & 3 & 4 & 5 \\
\hline $\begin{array}{l}\text { 11. Arkadaşlarım arasında kullanılan özel internet } \\
\text { terimlerini bilmek benim için önemlidir. }\end{array}$ & 1 & 2 & 3 & 4 & 5 \\
\hline $\begin{array}{l}\text { 12. Tatile gittiğimde arkadaşlarımın neler } \\
\text { yaptığını takip etmeye devam ederim. }\end{array}$ & 1 & 2 & 3 & 4 & 5 \\
\hline
\end{tabular}

Open Access This article is distributed under the terms of the Creative Commons Attribution 4.0 International License (http://creativecommons.org/licenses/by/4.0/), which permits unrestricted use, distribution, and reproduction in any medium, provided you give appropriate credit to the original author(s) and the source, provide a link to the Creative Commons license, and indicate if changes were made.

\section{References}

Abel, J. P., Buff, C. L., \& Burr, S. A. (2016). Social media and the fear of missing out: Scale development and assessment. Journal of Business \& Economics Research, 14(1), 33.

Bacanl, H., İlhan, T., \& Aslan, S. (2009). Development of a personality scale based on five factor theory: Adjective Based Personality Scale (ABPT). Journal of Turkish Educational Sciences, 7(2), 261-279.

Billieux, J., Maurage, P., Lopez-Fernandez, O., Kuss, D. J., \& Griffiths, M. D. (2015). Can disordered mobile phone use be considered a behavioral addiction? An update on current evidence and a comprehensive model for future research. Current Addiction Reports, 2, 154-162.

Billieux, J., Van der Linden, M., d'Acremont, M., Ceschi, G., \& Zermatten, A. (2007). Does impulsivity relate to perceived dependence on and actual use of the mobile phone? Applied Cognitive Psychology, 21(4), 527537.

Błachnio, A., \& Przepiorka, A. (2018). Be aware! If you start using Facebook problematically you will feel lonely: Phubbing, loneliness, self-esteem, and Facebook intrusion. A cross-sectional study. Social Science Computer Review. https://doi.org/10.1177/0894439318754490. 
Brand, M., Young, K. S., Laier, C., Wölfling, K., \& Potenza, M. N. (2016). Integrating psychological and neurobiological considerations regarding the development and maintenance of specific Internet-use disorders: An Interaction of Person-Affect-Cognition-Execution (I-PACE) model. Neuroscience \& Biobehavioral Reviews, 71, 252-266.

Chotpitayasunondh, V., \& Douglas, K. M. (2016). How "phubbing" becomes the norm: The antecedents and consequences of snubbing via smartphone. Computers in Human Behavior, 63, 9-18.

Demirci, K., Akgönül, M., \& Akpinar, A. (2015). Relationship of smartphone use severity with sleep quality, depression, and anxiety in university students. Journal of Behavioral Addictions, 4(2), 85-92.

Demyttenaere, K., Nijs, P., Evers-Kiebooms, G., \& Koninckx, P. R. (1989). The effect of a specific emotional stressor on prolactin, cortisol, and testosterone concentrations in women varies with their trait anxiety. Fertility and Sterility, 52(6), 942-948.

Elhai, J. D., Levine, J. C., Dvorak, R. D., \& Hall, B. J. (2016). Fear of missing out, need for touch, anxiety and depression are related to problematic smartphone use. Computers in Human Behavior, 63, 509-516.

Fetterman, A. K., Robinson, M. D., Ode, S., \& Gordon, K. H. (2010). Neuroticism as a risk factor for behavioral dysregulation: A mindfulness-mediation perspective. Journal of Social and Clinical Psychology, 29(3), 301-321.

Gonda, X., Fountoulakis, K. N., Juhasz, G., Rihmer, Z., Lazary, J., Laszik, A., Akiskal, H. S., \& Bagdy, G. (2009). Association of the s allele of the 5-HTTLPR with neuroticism-related traits and temperaments in a psychiatrically healthy population. European Archives of Psychiatry and Clinical Neuroscience, 259(2), 106-113.

Haenlein, M., \& Kaplan, A. M. (2004). A beginner's guide to partial least squares analysis. Understanding Statistics, 3(4), 283-297.

Hu, L. T., \& Bentler, P. M. (1999). Cutoff criteria for fit indexes in covariance structural analysis: Conventional criteria versus new alternatives. Structural Equation Modelling, 6(1), 1-55.

Jorm, A. F. (1989). Modifiability of trait anxiety and neuroticism: A meta-analysis of the literature. Australian \& New Zealand Journal of Psychiatry, 23(1), 21-29.

Karadağ, E., Tosuntaș, Ș. B., Erzen, E., Duru, P., Bostan, N., Șahin, B. M., et al. (2015). Determinants of phubbing, which is the sum of many virtual addictions: A structural equation model. Journal of Behavioral Addictions, 4(2), 60-74.

Kircaburun, K., Alhabash, S., Tosuntaș, Ș. B., \& Griffiths, M. D. (2018). Uses and gratifications of problematic social media use among university students: A simultaneous examination of the Big Five of personality traits, social media platforms, and social media use motives. International Journal of Mental Health and Addiction. https://doi.org/10.1007/s11469-018-9940-6.

Kircaburun, K., \& Griffiths, M. D. (2018a). Instagram addiction and the Big Five of personality: The mediating role of self-liking. Journal of Behavioral Addictions, 7(1), 158-170.

Kircaburun, K., \& Griffiths, M. D. (2018b). Problematic Instagram use: The role of perceived feeling of presence and escapism. International Journal of Mental Health and Addiction. https://doi.org/10.1007/s11469-0189895-7.

Krasnova, H., Abramova, O., Notter, I., \& Baumann, A. (2016). Why phubbing is toxic for your relationship: Understanding the role of smartphone jealousy among "Generation y" users. In Paper presented at European Conference in Information Systems. Istanbul: Turkey.

Kuss, D. J., \& Griffiths, M. D. (2011). Online social networking and addiction-A review of the psychological literature. International Journal of Environmental Research and Public Health, 8(9), 3528-3552.

Kuss, D. J., \& Griffiths, M. D. (2012). Internet gaming addiction: A systematic review of empirical research. International Journal of Mental Health and Addiction, 10(2), 278-296.

Kuss, D. J., \& Griffiths, M. D. (2017). Social networking sites and addiction: Ten lessons learned. International Journal of Environmental Research and Public Health, 14, 311.

Le Compte, W. A., \& Oner, N. (1976). Development of the Turkish edition of the State-trait anxiety inventory. Cross-Cultural Anxiety, 1, 51-67.

Marteau, T. M., \& Bekker, H. (1992). The development of a six-item short-form of the state scale of the Spielberger State-Trait Anxiety Inventory (STAI). British Journal of Clinical Psychology, 31(3), 301-306.

McCrae, R. R., \& John, O. P. (1992). An introduction to the five-factor model and its applications. Journal of Personality, 60(2), 175-215.

Mehroof, M., \& Griffiths, M. D. (2010). Online gaming addiction: The role of sensation seeking, self-control, neuroticism, aggression, state anxiety, and trait anxiety. Cyberpsychology, Behavior, And Social Networking, 13(3), 313-316.

Nasser, F., \& Wisenbaker, J. (2003). A Monte Carlo study investigating the impact of item parceling on measures of fit in confirmatory factor analysis. Educational and Psychological Measurement, 63(5), 729-757.

Oberst, U., Wegmann, E., Stodt, B., Brand, M., \& Chamarro, A. (2017). Negative consequences from heavy social networking in adolescents: The mediating role of fear of missing out. Journal of Adolescence, 55, 51-60.

Öner, N., \& Le Compte, v. A. (1985). State-Trait Anxiety Inventory handbook. Istanbul: Boğaziçi University Publishing. 
Pontes, H. M., Szabo, A., \& Griffiths, M. D. (2015). The impact of Internet-based specific activities on the perceptions of Internet addiction, quality of life, and excessive usage: a cross-sectional study. Addictive Behaviors Reports, 1, 19-25.

Przybylski, A. K., Murayama, K., DeHaan, C. R., \& Gladwell, V. (2013). Motivational, emotional, and behavioral correlates of fear of missing out. Computers in Human Behavior, 29(4), 1841-1848.

Roberts, J. A., \& David, M. E. (2016). My life has become a major distraction from my cell phone: Partner phubbing and relationship satisfaction among romantic partners. Computers in Human Behavior, 54, 134 141.

Statista. (2018a). Number of smartphone users worldwide from 2014 to 2020 (in billions). Retrieved 10 April, 2018, from: https:/www.statista.com/statistics/330695/number-of-smartphone-users-worldwide/.

Statista. (2018b). Number of smartphone users in Turkey from 2013 to 2022 (in millions). Retrieved 10 April, 2018, from: https:/www.statista.com/statistics/467181/forecast-of-smartphone-users-in-turkey/.

Wegmann, E., Oberst, U., Stodt, B., \& Brand, M. (2017). Online-specific fear of missing out and Internet-use expectancies contribute to symptoms of Internet-communication disorder. Addictive Behaviors Reports, 5 , $33-42$.

Xanidis, N., \& Brignell, C. M. (2016). The association between the use of social network sites, sleep quality and cognitive function during the day. Computers in Human Behavior, 55, 121-126. 